\title{
Selection of a mathematical model to describe the lactation curves of Jersey cattle
}

\author{
Soner Cankaya', Adnan Unalan² and Ercan Soydan' \\ 'Department of Animal Science, Faculty of Agriculture, Ondokuz Mayis University, Samsun, Turkey, ${ }^{2}$ Department of \\ Plant and Animal Science, Vocational School of Ulukisla, Nigde University, Ulukisla, Turkey
}

\begin{abstract}
The extent of the usefulness of a lactation model depends on how well it succeeds in imitating the biological lactation process and how well it adjust for environmental and other factors that could influence production. Therefore, the objective of this study was to compare five different lactation curve models (Wood, Cobby and Le Du, Wilmink, Exponential and Parabolic Exponential model), and to find the best model that provided a good description of the lactation curve of Jersey cattle herd. Data used in this study were the first to seventh lactation official milk yield records from monthly recording of 3630 lactations between 1984 and 2008 in the farm. The results showed that Wood model which has minimum residual standard deviation (3.562), maximum adjusted $\mathrm{R}^{2}$ value $(91.6 \%)$ and maximum persistency value (93.3\%) performed the best fit to the data and allowed a suitable description of the lactation curve. It was concluded that the Wood model provided accurate estimates of milk yield for all lactation numbers because this model was found to be more superior to the other models. Consequently, the usage of Wood model would provide some useful information on genetic improvement of the Jersey breed under pasture-based dry seasonal production systems.
\end{abstract}

Keywords: Jersey cattle, lactation curve model, milk yield, persistency

\section{Zusammenfassung}

\section{Auswahl eines Modells zur Beschreibung der Laktationskurve bei Jersey Rindern}

Die Nützlichkeit eines Laktationskurvenmodells hängt davon ab, mit welcher Genauigkeit die biologischen Vorgänge einer Laktation erfasst werden können und ob es dabei gelingt, Umwelteinflüsse und andere Faktoren, welche diese beeinflussen, gut abzubilden. Deshalb war es das Ziel dieser Studie, fünf unterschiedliche Laktationskurvenmodelle zu vergleichen (Wood, Cobby and Le Du, Wilmink, Exponential and Parabolic Exponential model), um jenes Modell herauszufinden, welches die beste Beschreibung der Laktationskurve von Jerseyrindern liefert. Ausgewertet wurden die Ergebnisse der monatlichen Milchleistungen von Kühen in der ersten bis siebten Laktation von insgesamt 3630 Laktationen eines Betriebes der Jahre 1984 bis 2008. Die Ergebnisse zeigen, dass sich das Wood Modell mit der geringsten Reststandardabweichung (3562), dem größten $R^{2}$-Wert $(91,6 \%)$ sowie dem höchsten Persistenzwert (93,3\%) am ehesten zur Beschreibung der Laktationskurve eignet. 
Das Wood Modell erbrachte die genauesten Schätzungen des Milchertrages in allen erfassten Laktationen und erwies sich damit allen anderen Modellen überlegen. Somit liefert die Anwendung des Wood Modells nützliche Informationen zur genetischen Verbesserung der Jersey Rasse bei Weidehaltung unter jahreszeitlich bedingt trockenen Produktionssystemen.

Schlüsselwörter: Jersey Rind, Laktationskurvenmodell, Milchertrag, Persistenz

\section{Introduction}

One of the main incomes is milk production for dairy cattle farms and therefore milk yield records are great deal of importance for the dairy herds. Estimation of annual total milk production and operating to breeding plans and management system according with that estimated value in dairy herds depend on both efficiency of milk recording system and accuracy of milk yield calculating methods in the herds. The shape of the lactation curve provides valuable information which is essential to evaluate the biological and economic efficiency of the animal or herd and is useful for genetic evaluation, health monitoring, feed management decisions and planning purposes (Sherchand et al. 1995, Kocak \& Ekiz 2008). Furthermore, advances in genetic selection and husbandry practice make today's dairy cattle quite different from those of only ten years ago, and are likely to have affected the shape of lactation curve of dairy cattle as well as milk yield. Today, ability of lactation curve models should be gone ahead to investigate because accurate knowledge of lactation curves has an important relevance to management and research of dairy production systems.

In general, lactation curves in dairy cattle reach to the peak yield after calving and then decrease steadily after peak yield to the drying off (Swalve \& Guo 1999). Some characters such as maximum daily milk production, lactating day of maximum milk production and lactation persistency can be obtained directly from the lactation curve models. Based on the information obtained from the curve, it can be used as a tool for selecting the breeding herds and for evaluating the existing lactating herds (Swalve 1995, Fadlelmoula et al. 2007). Also, knowing when to expect an animal to reach peak yield, would affect the feeding strategy followed, allowing economic management of feed to extent that would satisfy the animal's requirement during various stages of lactation, reduce cost, and possibly maintaining peak yield for as long as possible (Tozer \& Huffaker 1999, Grzesiak et al. 2003). For example, a rising portion of the curve indicates that cows should be given a higher plane of nutrition, and a declining portion of the curve indicates a lower plane of nutrition (Sherchand et al. 1995).

A lot of mathematical models as Wood, Cobby and Le Du, Wilmink etc. were used to describe the lactation curve of cows (Sherchand et al. 1995, Baffour-Awuah et al. 1996, Amin 2003, Bohlsen et al. 2003, Soysal et al. 2004, Val-Arreola et al. 2004, Lombaard 2006, Takma \& Akbas 2007). There was one study on the applications of the mathematical models for description of the lactation curve of Jersey under pasture-based dry seasonal production systems (Orman \& Yildirim 1998). The authors used a total of 45 standard milk yield records obtained from the first, the second and the third lactations of Jersey breed to estimate lactation curve in their study. Accordingly, the aims of this study were to compare Wood, Cobby and Le Du, Wilmink, Exponential and Parabolic Exponential model using official milk 
yield records from monthly recording of 3630 lactations, and to find the best model that provided a good description of the lactation curve for Jersey herds.

\section{Material and methods}

\section{Data source}

In this study, analysed data were first to seventh lactation official milk yield records from monthly recording of 3630 lactations, which consisted of test-day milk yield records of 911 first, 771 second, 637 third, 515 fourth, 397 fifth, 261 sixth and 137 seventh lactation numbers, between 1984 and 2008 (over 25 years) from Jersey cattle herd under pasture-based dry seasonal production system in Karakoy Agricultural State Farm in Samsun (Turkey). Also, each data set was composed of the test days and the total amount of milk at the morning and evening milking of the test days. Lactation length varied from 150 to 400 days.

\section{Mathematical models}

Five different models were applied to fit the milk yield data of individual lactations. The individual fit of lactations curves has been used in previous studies with the purpose of comparing models (Silvestre et al. 2006, Orman \& Yildirim 1998, Sherchand et al. 1995).

\section{The Wood Model.}

The mathematical model to describe the lactation curve of dairy cows proposed by Wood (1967) is one of the most popular models (Sherchand et al. 1995). Wood's equation is:

$$
Y_{t}=a t^{b} \exp (-c t)
$$

For all models, $Y_{t}$ is milk yield in lactation day $t$. The scaling factor $a$ represents yield at the beginning of lactation, $b$ is the inclining slope parameter up to peak yield, and $c$ is the declining slope parameter (Silvestre et al. 2006).

Peak yield $(P Y)$ was assumed as the maximum test day milk yield. Peak time (PT) was accepted as the test time, at which daily milk yield was maximum. PT values of the models were calculated by equalizing the first partial derivations of the functions to zero. $P Y$ values were found by replacing PT values in the functions (Cilek \& Keskin 2008). PY, PT and persistency $(P)$ values for this model:

$$
P Y=a(b / c)^{b} e^{-b} \quad P T=b / c \quad P=-(b+1) \ln (c)
$$

2. The Cobby and Le Du Model.

The model proposed by Cobby \& Le Du (1978) has the particularity that milk yield after peak is modeled as a linear decline function (Vargas et al. 2000). The Cobby and Le Du equation is:

$$
Y_{t}=a-b t-a \exp (-c t)
$$

\section{The Wilmink Model.}

The model proposed by Wilmink (1987) is a modification of Cobby and Le Du model, and $k$ is a related to the moment peak, which is about $50 \mathrm{~d}$ (Vargas et al. 2000). Wilmink equation is:

$$
Y_{t}=a+b \exp (-k t)+c t
$$

In the present study $k$ was assumed equal to 0.05 . 


\section{The Exponential Model.}

The model was proposed by Brody et al. in 1923 (Sherchand et al. 1995) using exponential decline function:

$$
Y_{t}=a \exp (-c t)
$$

5. The Parabolic Exponential Model.

The model of Sikka (1950) produced a truncated bell curve for milk yield:

$$
Y_{t}=a \exp \left(-b t+c t^{2}\right)
$$

Also, persistency $(P, \%)$ was calculated as;

$$
P(\%)=\frac{\sum_{i=1}^{k}\left(p_{i+1}\right) / p_{i}}{k} \times 100
$$

where $p_{i}$ is the yield of the record $i$ that starts at peak time and $k$ is the record number from peak time to end of lactation.

\section{Comparison criteria for models}

Goodness of the fit of models was evaluated according to following criteria (Vargas et al. 2000):

a) Adjusted multiple coefficient of determination $\left(R_{a d j}^{2}\right)$

$$
R_{\text {adj }}^{2}=1-[(n-1) /(n-p)] \times\left(1-R^{2}\right)
$$

where $R^{2}$ is the Multiple coefficient of determination, $\left[R^{2}=1-(R S S / T S S)\right]$; $R S S$ is the residual sum of squares, TSS is the total sum of squares, $n$ is the number of observations and $p$ is the number of parameters in the model. The $R^{2}$ value is an indicator measuring the proportion of total variation about the mean $\bar{Y}$ explained by the lactation curve model. The coefficient of determination lies always between 0 and 1 , and the fit of a model is satisfactory if $R^{2}$ is close to unity.

b) Residual standard deviation (RSD)

$$
R S D=\sqrt{R S S} / \sqrt{(n-p)}
$$

where RSS is the Residual sum of squares, $n$ is the number of observations and $p$ is the number of parameters in the model.

Adjusted $R^{2}$ and $R S D$ values are the most important criteria to compare the suitability of used lactation curve models in terms of expression of lactation milk yield properties (Fernández et al. 2002). Therefore, the best model is the one with the lowest RSD and the highest $R_{a d j}^{2}$ coefficient. The models were fitted to the data for determination the best fit lactation curve using Marquardt (MRT) method which was seen to be more practical and required less computing time than the other methods such as Conjugate Gradient, Nelder Mead, quasi Newton method etc. (Orman \& Yildirim 1998), from SAS software nonlinear regression procedure, providing least square estimates of the parameters $a, b$ and $c$ (PROC NLIN procedure) (SAS 1988). 


\section{Results and discussion}

For overall lactation numbers, the parameters, adjusted $R_{2}$ and $R S D$ values of the models were given using five different lactation models - Wood, Cobby and Le Du, Wilmink, exponential and parabolic exponential - according to the milk yield ( $\mathrm{kg}$ ) at the test days (Table 1). Also, the lactation curves for the models were given in Figure. Table 1 and Figure showed that all of the lactation numbers taken into consideration, the explanatory capacities of studied lactation curve models apart from the Wilmink model which were quite high in the total variation belonging to milk yields of Jersey cows, and were close to each other due to maximum $R_{a d j}^{2}$ (ranged from 0.914 to 0.916 ) and minimum $R S D$ (ranged from 3.562 to 3.580 ) values. Although the ability of a model depends on the construction of data, this high level of accuracy for the models has also been reported in previous studies fitting models on mean milk yields of Holstein cows (Vargas et al. 2000) and Simmental cows (Macciotta et al. 2005, Cilek \& Keskin 2008). According to the present result and previous result, it can be said that appropriated models are chosen for used data to explain the lactation curve of Jersey cows. Furthermore, the ability of Cobby and Le Du, exponential and parabolic exponential and especially the Wood model was presented an idea that how well it succeeds in imitating the biological lactation process and how well it adjust for environmental and other factors that could influence production (Olori et al. 1999). Moreover, this study showed that the Wood model should adequately mimic factors affecting the biological process of lactation, such as cow's genetic merit, breed, parity, calving season, nutrition, and pregnancy, the shape of her lactation curve (Tozer \& Huffaker 1999).

Table 1

The parameters and goodness of fit measurements of overall lactation curve models for each lactation numbers

\begin{tabular}{|c|c|c|c|c|c|}
\hline \multirow[t]{2}{*}{ Models } & \multicolumn{3}{|c|}{ Parameters } & \multirow[t]{2}{*}{$\mathrm{R}_{\mathrm{adj}}^{2}$} & \multirow[t]{2}{*}{ RSD } \\
\hline & $\mathrm{a} \pm \mathrm{s}_{\bar{a}}$ & $b \pm s_{b}$ & $c \pm s_{\bar{c}}$ & & \\
\hline Wood & $15.46 \pm 0.051$ & $0.12 \pm 0.007$ & $0.09 \pm 0.002$ & 0.916 & 3.562 \\
\hline Cobby and Le Du & $15.78 \pm 0.049$ & $0.70 \pm 0.007$ & $2.74 \pm 0.002$ & 0.916 & 3.564 \\
\hline Wilmink & $19.04 \pm 1.982$ & $-3.78 \pm 2.035$ & $-0.80 \pm 0.076$ & 0.852 & 3.573 \\
\hline Exponential & $15.81 \pm 0.047$ & - & $0.06 \pm 0.001$ & 0.914 & 3.580 \\
\hline Parabolic Exponential & $15.02 \pm 0.072$ & $0.03 \pm 0.002$ & $-0.003 \pm 0.0002$ & 0.915 & 3.570 \\
\hline
\end{tabular}

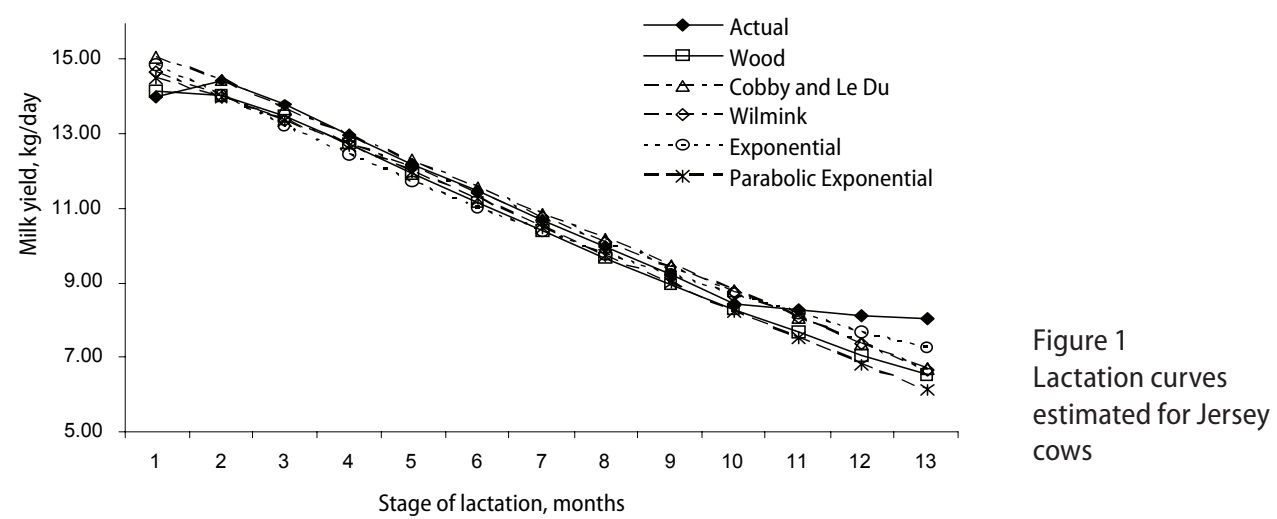


The results with respect to $R_{a d j}^{2}$ and $R S D$ values of the model (Table 1) indicated that the Wood model was the best model for explaining properties of milk yield of Jersey cows because of the lowest RSD (3.562) and the largest $R^{2}$ coefficient (91.6\%) while the performance of Wilmink model is lower when compared with the other lactation curve models. On the other hand, this matter may provide advantages to researchers in practice because the model can be linearized with a simple logarithmic transformation and easily solved by ordinary least squares analysis (Tekerli et al. 2000).

For each lactation numbers (first to seventh), estimated parameters, adjusted $R^{2}$ and RSD values of Wood, Cobby and Le Du, Wilmink, exponential and parabolic exponential models were given in Table 2. Apart from Wilmink model, goodness of fit of lactation curve models for each lactation numbers of Jersey which was quite high and close to each other due to maximum $R_{a d j}^{2}$ and minimum RSD values. The Wood model has the lowest $R S D$ values (ranged from 2.946 to 4.050) and the highest $R^{2}$ coefficients (ranged from 90.8 to $93.3 \%$ ), and accordingly, the Wood model was the best model for explaining properties of milk yield of Jersey. On the other hand, the performance of the Wilmink model was lower (approximately 16.8-21.2\%) when compared with the other models due to minimum $R_{a d j}^{2}$ and high $R S D$ values of the model. Therefore, the Wilmink model should not be preferred to explain lactation curve characteristics of Jersey.

Although the results of the Wood model were very close to those of Cobby and Le Du model, it can propose the Wood model as the best model for estimating to the researchers studying on dairy cows under pasture-based dry seasonal production system. When the Cobby and Le Du model were, also, compared to the Wood model in terms of peak yield, peak time and persistency (\%) values (Table 3), the Wood model can preference. Indeed, Table 3 showed that peak milk yield (15.61-15.87 kg) was reached at 42-45th days of sixth lactation number of Jersey cows. The highest persistency value showing positive impact on subsequent lactations was estimated by the parameters of the Wood model in first lactation. This value decreased at low rates in subsequent lactation in both models. This high level of persistency for the first lactation has also been reported in previous studies (Wood 1967, Swalve \& Guo 1999, Cagan \& Ozyurt 2008). These findings can be interpreted as the characters of first lactation are flatter than those of other lactation numbers. Hence, the Wood model can be preferred for lactation curves in terms of a healthy growing and production program of Jersey herds. With usage of this model, both the highest $R_{a d j}^{2}$ and the lowest $R S D$ values, lactation milk yields of Jersey cows which are dried off due to unpredictable reasons (illness, injury etc.) can be estimated, and also missing test day milk yields would be predicted. Thus, it can be decided whether a cow can be kept in the herd in terms of milk yields in the first lactation and also in the early stages of the lactation period. If possible shape of the lactation curve is known, dairy cows can be grouped (high, average and low) according to expected lactation milk yields. Then, more suitable nutrition programs can be created for requirements of each group by taking into consideration differences among the groups. As a result, it can be apparently declared that the Wood model can be used for management decisions and genetic evaluation of Jersey cows for milk production. 
Table 2

The parameters and goodness of fit measurements of all lactation curve models for each lactation numbers

\begin{tabular}{|c|c|c|c|c|c|c|}
\hline \multirow[t]{2}{*}{ Models } & \multicolumn{4}{|c|}{ Parameters } & \multirow[t]{2}{*}{$\mathrm{R}_{\mathrm{adj}}^{2}$} & \multirow[t]{2}{*}{ RSD } \\
\hline & $a \pm s_{a}$ & $b \pm s_{\bar{b}}$ & & $\pm \pm s_{\bar{c}}$ & & \\
\hline \multicolumn{7}{|l|}{ First Lactation } \\
\hline Wood & $13.13 \pm 0.081$ & $0.12 \pm 0.012$ & 0.06 & \pm 0.003 & 0.933 & 2.946 \\
\hline Cobby and Le Du & $13.76 \pm 0.082$ & $0.47 \pm 0.012$ & 2.48 & \pm 0.105 & 0.933 & 2.944 \\
\hline Wilmink & $27.11 \pm 3.221$ & $-14.18 \pm 3.309$ & -0.94 & \pm 0.123 & 0.770 & 2.955 \\
\hline Exponential & $13.49 \pm 0.072$ & - & 0.04 & \pm 0.001 & 0.931 & 2.962 \\
\hline Parabolic Exponential & $12.82 \pm 0.113$ & $0.01 \pm 0.004$ & -0.003 & $3 \pm 0.0003$ & 0.932 & 2.954 \\
\hline \multicolumn{7}{|l|}{ Second Lactation } \\
\hline Wood & $14.99 \pm 0.103$ & $0.13 \pm 0.014$ & 0.09 & \pm 0.004 & 0.922 & 3.321 \\
\hline Cobby and Le Du & $15.29 \pm 0.101$ & $0.69 \pm 0.014$ & 2.73 & \pm 0.149 & 0.922 & 3.322 \\
\hline Wilmink & $21.22 \pm 4.137$ & $-6.49 \pm 4.247$ & -0.88 & \pm 0.159 & 0.767 & 3.331 \\
\hline Exponential & $15.33 \pm 0.095$ & - & 0.06 & \pm 0.001 & 0.921 & 3.339 \\
\hline Parabolic Exponential & $16.02 \pm 0.184$ & $0.04 \pm 0.005$ & -0.002 & $2 \pm 0.0004$ & 0.915 & 3.684 \\
\hline \multicolumn{7}{|l|}{ Third Lactation } \\
\hline Wood & $16.37 \pm 0.126$ & $0.11 \pm 0.016$ & 0.09 & \pm 0.004 & 0.915 & 3.676 \\
\hline Cobby and Le Du & $16.34 \pm 0.121$ & $0.77 \pm 0.017$ & 3.10 & \pm 0.246 & 0.915 & 3.683 \\
\hline Wilmink & $7.17 \pm 4.971$ & $9.12 \pm 5.103$ & -0.39 & \pm 0.191 & 0.783 & 3.687 \\
\hline Exponential & $16.56 \pm 0.118$ & - & 0.06 & \pm 0.001 & 0.915 & 3.690 \\
\hline Parabolic Exponential & $16.02 \pm 0.184$ & $0.04 \pm 0.005$ & -0.002 & $2 \pm 0.0004$ & 0.915 & 3.684 \\
\hline \multicolumn{7}{|l|}{ Fourth Lactation } \\
\hline Wood & $16.93 \pm 0.144$ & $0.14 \pm 0.017$ & 0.10 & \pm 0.004 & 0.915 & 3.741 \\
\hline Cobby and Le Du & $16.97 \pm 0.136$ & $0.85 \pm 0.019$ & 2.92 & \pm 0.223 & 0.914 & 3.746 \\
\hline Wilmink & $15.91 \pm 5.469$ & $0.73 \pm 0.562$ & -0.78 & \pm 0.210 & 0.817 & 3.754 \\
\hline Exponential & $17.34 \pm 0.158$ & - & 0.06 & \pm 0.002 & 0.911 & 3.907 \\
\hline Parabolic Exponential & $16.29 \pm 0.207$ & $0.04 \pm 0.006$ & -0.003 & $3 \pm 0.0005$ & 0.914 & 3.750 \\
\hline \multicolumn{7}{|l|}{ Fifth Lactation } \\
\hline Wood & $16.89 \pm 0.170$ & $0.15 \pm 0.020$ & 0.10 & \pm 0.005 & 0.912 & 3.879 \\
\hline Cobby and Le Du & $17.23 \pm 0.163$ & $0.85 \pm 0.023$ & 2.62 & \pm 0.194 & 0.912 & 3.880 \\
\hline Wilmink & $26.18 \pm 6.440$ & $-9.70 \pm 6.615$ & -1.15 & \pm 0.247 & 0.894 & 3.893 \\
\hline Exponential & $17.34 \pm 0.158$ & - & 0.06 & \pm 0.002 & 0.910 & 3.907 \\
\hline Parabolic Exponential & $16.14 \pm 0.241$ & $0.03 \pm 0.006$ & -0.004 & $4 \pm 0.0006$ & 0.911 & 3.889 \\
\hline \multicolumn{7}{|l|}{ Sixth Lactation } \\
\hline Wood & $17.31 \pm 0.207$ & $0.15 \pm 0.024$ & 0.11 & \pm 0.006 & 0.916 & 3.308 \\
\hline Cobby and Le Du & $17.50 \pm 0.198$ & $0.88 \pm 0.028$ & 2.68 & \pm 0.246 & 0.916 & 3.815 \\
\hline Wilmink & $15.94 \pm 7.906$ & $1.12 \pm 0.812$ & -0.78 & \pm 0.303 & 0.820 & 3.827 \\
\hline Exponential & $17.73 \pm 0.194$ & - & 0.07 & \pm 0.002 & 0.914 & 3.836 \\
\hline Parabolic Exponential & $16.66 \pm 0.297$ & $0.03 \pm 0.008$ & -0.003 & $3 \pm 0.0007$ & 0.915 & 3.822 \\
\hline \multicolumn{7}{|l|}{ Seventh Lactation } \\
\hline Wood & $16.62 \pm 0.295$ & $0.13 \pm 0.035$ & 0.09 & \pm 0.008 & 0.908 & 4.050 \\
\hline Cobby and Le Du & $17.04 \pm 0.285$ & $0.75 \pm 0.040$ & 2.60 & \pm 0.338 & 0.908 & 4.051 \\
\hline Wilmink & $20.21 \pm 11.04$ & $-3.76 \pm 1.135$ & -0.83 & \pm 0.421 & 0.835 & 4.065 \\
\hline Exponential & $17.04 \pm 0.270$ & - & 0.06 & \pm 0.003 & 0.906 & 4.070 \\
\hline Parabolic Exponential & $16.19 \pm 0.416$ & $0.03 \pm 0.011$ & -0.002 & $2 \pm 0.0009$ & 0.907 & 4.062 \\
\hline
\end{tabular}


Table 3

Peak yield (PY), peak time (PT) and persistency $(P)$ values for each lactation numbers

\begin{tabular}{lcccccc}
\hline $\begin{array}{l}\text { Lactation } \\
\text { period }\end{array}$ & $\mathrm{PY}, \mathrm{kg}$ & $\begin{array}{c}\text { Wood } \\
\mathrm{PT} \text {, day }\end{array}$ & $\mathrm{P}, \%$ & $\mathrm{PY}, \mathrm{kg}$ & $\begin{array}{c}\text { Cobby and Le Du } \\
\mathrm{PT}, \text { day }\end{array}$ & $\mathrm{P}, \%$ \\
\hline 1 & 12.66 & 61.0 & 96.1 & 12.76 & 52.70 & 95.4 \\
2 & 13.81 & 44.1 & 93.4 & 14.00 & 45.83 & 93.1 \\
3 & 14.99 & 37.3 & 93.1 & 15.05 & 41.19 & 92.6 \\
4 & 15.43 & 42.7 & 92.7 & 15.50 & 42.47 & 91.7 \\
5 & 15.45 & 45.8 & 92.8 & 15.62 & 46.24 & 91.9 \\
6 & 15.61 & 41.6 & 91.9 & 15.87 & 45.25 & 91.7 \\
7 & 15.31 & 44.1 & 93.4 & 15.57 & 47.85 & 93.3 \\
Overall & 14.19 & 40.7 & 93.3 & 14.47 & 45.90 & 93.2 \\
\hline
\end{tabular}

\section{Acknowledgements}

This study was supported by TOVAG-107 0338 Project of Tubitak. The authors wish to thank the staff of Karakoy State Farm for technical assistance and the Dr. N Ocak for his critical editing of the manuscript.

\section{References}

Amin AA (2003) Test-day model of daily milk yield prediction across stages of lactation in Egyptian buffalos. Arch Tierz 46, 35-45

Baffour-Awuah O, Brotherstone S, Hill WG (1996) Genetic analysis of test day production in second lactation of British Holstein Friesian cows. Arch Tierz 39, 213-226

Bohlsen E, Waßmuth R, Ordolff D (2003) Reliability of milk recording applying automatic milking - comparision of German and Canadian model approaches. Arch Tierz 46, 3-15 [in German]

Brody S, Ragsdale AC, Turner CW (1923) The rate of decline of milk secretion with the advance of the period of lactation. J Gen Physiol 5, 441-444

Cagan V, Ozyurt A (2008) Parameter estimates for lactation curve of Holstein Friesian in Polatli Agriculture Administration. J Anim Prod 49, 5-12

Cilek S, Keskin I (2008) Comparison of six different mathematical models to the lactation curve of Simmental cows reared in Kazova State Farm. J Anim Vet Adv 7, 1316-1319

Cobby JM, Le Du YLP (1978). On fitting curves to lactation data. Anim Prod 26, 127-133

Fadlelmoula AA, Yousif IA, Abu Nikhaila AM (2007) Lactation curve and persistency of crossbred dairy cows in the Sudan. J Appl Sci Res 3, 1127-1133

Fernández C, Sánchez A, Garcés C (2002) Modeling the lactation curve for test-day milk yield in MurcianoGranadina goats. Small Rumin Res 46, 29-41

Grzesiak W, Wojcik J, Binerowska B (2003) Prediction of 305-day first lactation milk yield in cows with selected regression models. Arch Tierz 46, 215-226

Kocak Ö, Ekiz B (2008) Comparison of different lactation curve models in Holstein cows raised on a farm in the south-eastern Anatolia region. Arch Tierz 51, 329-337

Lombaard CS, (2006) Hierarchical bayesian modelling for the analysis of the lactation of dairy animals. PhD Thesis, University of the Free State, Bloemfontein, South Africa

Macciotta NPP, Vicario D, Cappio-Borlino A (2005) Detection of different shapes of lactation curve for milk yield in dairy cattle by empirical mathematical models. J Dairy Sci 88, 1178-1191

Olori VE, Brotherstone S, Hill WG, McGuirk BJ (1999) Fit of standard models of the lactation curve to weekly records of milk production of cows in a single herd. Livest Prod Sci 58, 55-63 
Orman MN, Yildirim F (1998) Statistical description of lactation curve of Jersey Breed in Karakoy State Farm. Turk J Vet Anim Sci 22, 131-135

SAS Institute Inc. (1988) SAS User's guide: statistics, v6. SAS Institute Inc., Cary, NC, USA

Sherchand L, Mcnew RW, Kellogg DW, Johnson ZB (1995) Selection of a mathematical model to generate lactation curves using daily milk yields of Holstein cows. J Dairy Sci 78, 2507-2513

Sikka LC (1950). A Study of Lactation as affected by heredity and environment. J Dairy Res 17, 231

Silvestre AM, Petim-Batista F, Colaço J (2006) The Accuracy of seven mathematical functions in modeling dairy cattle lactation curves based on test-day records from varying sample schemes. J Dairy Sci 89, 1813-1821

Soysal MI, Sirlar FG, Gurcan EK (2004) An Investigation on the lactation biometry of black and white dairy cattle herds raised in some public intensive farms in Turkey. Trakia J Sci 2, 54-58

Swalve HH (1995) Test day models in the analysis of dairy production data - a review. Arch Tierz 38, 591-612

Swalve HH, Guo Z (1999) An illustration of lactation curves stratified by lactation yields within herd. Arch Tierz 42, 515Takma C, Akbas Y (2007) Estimates of genetic parameters for test day milk yields of a Holstein Friesian herd in Turkey with random regression models. Arch Tierz 50, 327-336

Tekerli M, Akinci Z, Dogan I, Akcan A (2000) Factors Affecting the Shape of Lactation Curves of Holstein Cows from the Balikesir Province of Turkey. J Dairy Sci 83, 1381-1386

Tozer, PR, Huffaker RG (1999) Mathematical equations to describe lactation curves for Holstein-Friesian cows in New South Wales. Aust J Agric Res 50, 431-440

Val-Arreola D, Kebreab E, Dijkstra J, France J (2004) Study of the lactation curve in dairy cattle on farms in central Mexico. J Dairy Sci 87, 3789-3799

Vargas B, Koops WJ, Herrero M, Van Arendonk JAM (2000). Modeling extended lactations of dairy cows. J Dairy Sci 83, 1371-1380

Wilmink JBM (1987) Adjustment of test-day milk, fat and protein yield for age, season and stage of lactation. Livest Prod Sci 16, 335-348

Wood PDP (1967) Algebraic model of the lactation curve in cattle. Nature 216, 164-165

Received 31 August 2009, accepted 29 November 2010.

Corresponding author:

Soner Cankaya

email: scankaya@omu.edu.tr

Zootekni Bölümü, Ziraat Fakültesi, Ondokuz Mayıs Üniversitesi, 55139-Atakum, Samsun, Turkey 